\title{
Genetic parameters for milk yield and reproduction traits in the Chilean Dairy Overo Colorado cattle breed
}

\author{
Hugo H. Montaldo ${ }^{1}$, Carlos Trejo ${ }^{2}$, and Carlos Lizana ${ }^{2}$ \\ ${ }^{1}$ Universidad Nacional Autónoma de México, Facultad de Medicina Veterinaria y Zootecnia, Departamento \\ de Genética y Bioestadística. Ciudad Universitaria, 04510, Ciudad de México, México. \\ ${ }^{2}$ Cooperativa Agrícola y de Servicios (COOPRINSEM). Manuel Rodríguez 1040, Osorno, Región de los \\ Lagos, Chile.
}

\begin{abstract}
H.H. Montaldo, C. Trejo, and C. Lizana. 2017. Genetic parameters for milk yield and reproduction traits in the Chilean Dairy Overo Colorado cattle breed. Cien. Inv. Agr. 44(1): 24-34. The objective of this study was to estimate genetic parameters for milk production and reproduction traits using phenotypic and pedigree information from the Dairy Overo Colorado breed from southern Chile. Single- and multi-trait mixed models were used to analyze the data. Analyses were performed using ASReml software. The heritability estimates for milk yield, fat yield, protein yield, fat content, protein content, age at first calving and calving interval were $0.29 \pm 0.04,0.34 \pm 0.04,0.30 \pm 0.04,0.56 \pm 0.04,0.56 \pm 0.04,0.01 \pm$ 0.07 and $0.002 \pm 0.02$, respectively. The genetic correlations between yield traits were high and positive $(\geq 0.81)$. The genetic correlations of milk yield with fat content $(-0.32)$ and protein content $(-0.34)$ were unfavorable. The genetic correlation estimates between age at first calving and yield traits were negative, ranging between -0.71 and -0.29 . The phenotypic correlations between calving interval and milk yield traits were slightly positive (0.06-0.09), suggesting a weak relationship between reproduction and yield in this population. Genetic variation was significantly greater than zero for milk production traits. Genetic improvement for age at first calving and calving interval may be slow because small differences between animals and low reliabilities are expected for estimated breeding values for these traits due to heritabilities close to zero. The design of an efficient breeding program for yield traits based on artificial insemination for this population is feasible using either progeny testing or genomic breeding value prediction to select sires.
\end{abstract}

Key words: Breeding, Chile, correlation, heritability, local cattle breed.

\section{Introduction}

The Overo Colorado is a local red and white cattle population in Chile, originating in the 19 th century from animals imported from

Received May 07, 2016. Accepted January 17, 2017. Corresponding author: montaldo@unam.mx central Europe, mainly from the German Red Pied (Rotbunte) breed. Although it was initially considered a dual-purpose breed (FAO, 2007), there are currently two subpopulations of Overo Colorado in the country: one considered dual purpose (meat and milk production) and another mainly oriented toward milk production (Dairy Overo Colorado). The Dairy Overo Colorado 
population is mostly found in Southern Chile, particularly in the regions of Bío-Bío and Aysen ( $36^{\circ}$ to $49^{\circ}$ latitude south), and is typically raised in temperate oceanic climates, primarily using grazing-based production systems (ODEPA, 2010). A genetic improvement program for this breed has been under development. This program is based on progeny testing of bulls maintained at the artificial insemination (AI) center of the Universidad Austral de Chile based on records obtained by the recording system of COOPRINSEM, a private agricultural services company (FAO, 2007; Ferreira et al., 2010).

Although reliable genetic parameter estimates for economically important traits are available for many populations of dairy cattle associated with the International Bull Evaluation Service (Mark, 2004), estimates from many local populations are lacking. Knowledge of genetic parameters is needed to develop efficient breeding programs for local breeds insofar as this may help reduce the risk of population loss, which is a serious threat to global genetic diversity in domestic animals (FAO, 2007).

Currently, reproduction traits, including calving interval, have been incorporated in routine genetic evaluations of dairy cattle in practically all existing breeding programs worldwide, which is a recognition of their importance to the economics and welfare of dairy cattle production (VanRaden et al., 2004; Oltenacu \& Broom, 2010).

Heritability estimates using a single-trait mixed model and Restricted Maximum Likelihood methodology have been obtained for some milk production traits in the Chilean Overo Colorado (Uribe \& Smulders, 2004). However, no study has focused on evaluating genetic parameters in the Dairy Overo Colorado population using multi-trait models; therefore, to date, no estimates of genetic correlations or genetic parameters for reproduction traits are available.

The objective of this study was to estimate genetic parameters for milk production (milk yield, fat yield, protein yield, fat content, protein content) and reproduction traits (age at first calving, calving interval), using multi-trait models, with information from Dairy Overo Colorado cattle obtained in Southern Chile.

\section{Material and methods}

The milk data analyzed in the present study were obtained between 1997 and 2008 from the recording system of COOPRINSEM, Osorno, Chile, from 46 herds in Southern Chile. Records from 7,650 complete lactations and 3,017 cows for milk yield (MY), fat yield (FY) and protein yield (PY) standardized to a 305-day mature equivalent basis were analyzed. Fat content (FC) and protein content (PC) were obtained from ratios of yields. Calving interval (CI) and age at first calving (AF) were estimated from birth and calving dates. Records for CI $(3,488)$ were obtained from 1997 to 2008 from 1772 cows in 38 herds. Records for AF were obtained from 1997 to 2008 from 2,043 cows in 42 herds. Noticeably erroneous data and data outside the normal acceptable ranges for CI and AF (Table 1), which were less than $0.3 \%$ of total records for each trait, were excluded from the final analysis. Pedigree information was complete (sire and dam) for all cows with records. The use of AI is extensive in this population; therefore, connections due to the use of the same sires in different herds were common.

In this study, only data from animals defined as Dairy Overo Colorado cows with dams from herds classified as purebred, i.e., having a purebred sire and a purebred maternal grandsire, were kept for analysis. All cows in the data set had complete sire and dam identification, which traced back to base animals born in 1994. Sires born in Chile and in Germany from the German Red Pied (Rotbunte) breed were included in the pedigree. Currently, animals with up to $25 \%$ of another breed (mainly red Holstein) are accepted in the herd book for the Dairy Overo Colorado population. 
Table 1. Descriptive statistics for Dairy Overo Colorado cattle data.

\begin{tabular}{lccccccc}
\hline & \multicolumn{1}{c}{ Trait } \\
\cline { 2 - 9 } Parameter & $\begin{array}{c}\text { Age at first } \\
\text { calving (days) }\end{array}$ & $\begin{array}{c}\text { Calving } \\
\text { interval (days) }\end{array}$ & $\begin{array}{c}\text { Milk yield } \\
(\mathrm{kg})\end{array}$ & $\begin{array}{c}\text { Fat yield } \\
(\mathrm{kg})\end{array}$ & $\begin{array}{c}\text { Protein } \\
\text { yield (kg) }\end{array}$ & $\begin{array}{c}\text { Fat } \\
\text { content } \\
(\%)\end{array}$ & $\begin{array}{c}\text { Protein } \\
\text { content } \\
(\%)\end{array}$ \\
\hline No. of observations & 2,043 & 3,488 & 7,650 & 7,650 & 7,650 & 7,650 & 7,650 \\
Mean & 913 & 374 & 5,888 & 215 & 194 & 3.66 & 3.30 \\
Standard deviation & 129 & 54 & 1,396 & 53 & 46 & 0.39 & 0.21 \\
Minimum value & 561 & 294 & 1,573 & 33 & 51 & 2.10 & 2.46 \\
Maximum value & 1,352 & 730 & 13,394 & 472 & 452 & 5.57 & 4.36 \\
\hline
\end{tabular}

Statistical analyses were conducted using ASReml software version 3.0 (Gilmour et al., 2009). Traits measured during several lactations (MY, FY, PY, FC and PC) and CI were first analyzed using single-trait mixed linear models that included herd-year-season of calving and parity-season as fixed effects as well as animal (with the inverse of the additive numerator relationship matrix $\mathrm{A}^{-1}$ obtained from pedigree), permanent environmental and sire-herd random effects. AF was analyzed with a similar model, but using only first parity data, excluding permanent environmental effects, using herd-year-season of birth rather than herd-year-season of calving, and excluding parity-season effects. Based on climatic and management differences and on calving distributions, three four-month seasons were defined: (1) January-April, (2) May-August and (3) September-December. The definitions of model equations and assumptions used for single- and multi-trait analyses were similar to those described by Montaldo et al. (2015).

Thereafter, four three-trait model analyses for estimating all (co)variances involving MY, FY, PY, FC and PC were made. Model A contained MY, FY and PY; model B contained MY, FC and PC; model C contained FY, FC and PC; and model D contained PY, FC and PC. Multi-trait models contained the same fixed and random effects used in single-trait analyses. (Co)variance matrices were estimated for animal, permanent environmental and residual effects. Sire-herd effects were included in the models for each trait as uncorrelated random effects. All single- and multi-trait model runs involving milking traits converged (Gilmour et al., 2009).

Different modeling strategies were required in order to estimate covariances associated with $\mathrm{AF}$ and CI, insofar as the small values of the additive genetic variance estimates for these two traits made convergence difficult. Bivariate analyses (Model E), involving AF and CI with first calving data with variances fixed to achieve convergence, yielded genetic correlation estimates outside the parametric space; therefore, the genetic covariance was set to zero and only phenotypic correlation results from the analysis of these traits are reported. A multi-trait model involving AF, MY, FY and PY (Model F), with similar effects to those previously described for the single-trait analysis for AF, was also fitted using first-calving data. To achieve convergence for this analysis, estimates of residual and animal variances for all traits and covariances involving MY, FY and PY, obtained from two- and three-trait models that achieved convergence, were fixed. Twotrait analyses involving CI with MY, FY or PY (Models G, H and I), containing the same fixed and random effects used in single-trait analyses, were also performed.

As an approximation, any genetic parameter value was considered significantly different from zero when the absolute value of the estimate was more than twice the standard error (Åkesson et al., 2008). 


\section{Results}

Descriptive statistics are displayed in Table 1. Values of heritability, repeatability and phenotypic variance from single-trait analyses are shown in Table 2.

The repeatability estimates for CI, MY, FY, PY, FC and PC were all higher than the corresponding heritability, indicating the presence of either permanent environmental or genetic dominance effects. The standard errors for heritabilities indicate that only values for MY, FY, PY, FC and $\mathrm{PC}$ are different from zero. The proportion of variance explained by sire-herd effects was relatively small and lower than heritability for most traits, with the exception of AF.

Table 3 displays parameter estimates from multitrait models involving milk traits. Estimates of phenotypic variance, heritability, repeatability and proportion of sire-herd effects were similar between multi-trait models and similar to estimates from single-trait model analyses.

Table 4 shows estimates of genetic and phenotypic correlations using different models. The genetic correlations between yield traits were high $(\geq$ 0.81 ) and different from zero. The phenotypic correlations for these traits were slightly lower, indicating positive correlations between random environmental effects. The genetic correlations between MY and FC (-0.32) and between MY and PC $(-0.34)$ were moderately negative. The genetic correlations between FY and FC (0.51) and between PY and PC (0.13) were not different from zero.

The genetic correlation between $\mathrm{AF}$ and $\mathrm{CI}$ was not estimable, so the genetic covariance was fixed at zero. The phenotypic correlation between AF and CI was close to zero. Genetic correlation estimates relating $\mathrm{AF}$ and $\mathrm{CI}$ with milk traits were obtained by fixing additive genetic (co)variances as required to achieve convergence. The genetic correlations between AF and MY (-0.71) and between AF and PY (-0.65) were negative, suggesting that selection for increased MY and PY would lead to a favorable response in AF. The genetic correlation estimates between $\mathrm{CI}$ and milk yield traits have such high standard errors that they could not be considered different from zero and therefore were not reported. The phenotypic correlations between $\mathrm{CI}$ and milk yield traits were slightly positive (0.06-0.09), suggesting a weak relationship between reproduction and yield in this population.

\section{Discussion}

The AF average and variability in this population (913 days, $\mathrm{SD}=129)$ were high compared to those of New Zealand cattle $(732, \mathrm{SD}=23$ days $)$

Table 2. Estimates of genetic parameters from single-trait model analyses for Dairy Overo Colorado cattle.

\begin{tabular}{|c|c|c|c|c|c|c|c|}
\hline \multirow[b]{2}{*}{ Parameter } & \multicolumn{7}{|c|}{ Trait } \\
\hline & $\begin{array}{l}\text { Age at first } \\
\text { calving }\end{array}$ & $\begin{array}{l}\text { Calving } \\
\text { interval }\end{array}$ & Milk yield & Fat yield & $\begin{array}{l}\text { Protein } \\
\text { yield }\end{array}$ & Fat content & Protein content \\
\hline $\begin{array}{l}\text { Phenotypic } \\
\text { variance }\end{array}$ & 6,109 & 2,698 & 902,590 & 1,314 & 902 & 0.132 & 0.034 \\
\hline Heritability & $0.01 \pm 0.07$ & $0.002 \pm 0.020$ & $0.29 \pm 0.04$ & $0.34 \pm 0.04$ & $0.30 \pm 0.04$ & $0.559 \pm 0043$ & $0.560 \pm 0042$ \\
\hline $\begin{array}{l}\text { Proportion } \\
\text { of sire-herd } \\
\text { variance }\end{array}$ & $0.10 \pm 004$ & 0.000 & $0.04 \pm 0.02$ & $0.05 \pm 0.02$ & $0.05 \pm 0.02$ & $0.005 \pm 0013$ & 0.000 \\
\hline Repeatability & - & $0.046 \pm 0.025$ & $0.51 \pm 0.02$ & $0.50 \pm 0.02$ & $0.50 \pm 0.02$ & $0.723 \pm 0015$ & $0.747 \pm 0009$ \\
\hline
\end{tabular}


Table 3. Estimates of genetic parameters from multi-trait model analysis for Dairy Overo Colorado cattle.

\begin{tabular}{|c|c|c|c|c|c|c|}
\hline \multirow[b]{2}{*}{ Parameter } & \multicolumn{5}{|c|}{ Trait } & \multirow[b]{2}{*}{ Model $\dagger$} \\
\hline & $\begin{array}{l}\text { Milk yield } \\
\text { (MY) }\end{array}$ & $\begin{array}{l}\text { Fat yield } \\
\text { (FY) }\end{array}$ & $\begin{array}{l}\text { Protein } \\
\text { yield (PY) }\end{array}$ & $\begin{array}{l}\text { Fat content } \\
\quad(\mathrm{FC})\end{array}$ & $\begin{array}{c}\text { Protein } \\
\text { content }(\mathrm{PC})\end{array}$ & \\
\hline \multirow[t]{4}{*}{ Phenotypic variance } & 897,490 & 1,300 & 897 & - & - & A \\
\hline & 902,680 & - & - & 0.132 & 0.034 & B \\
\hline & - & 1,307 & - & 0.132 & 0.034 & $\mathrm{C}$ \\
\hline & - & - & 902 & 0.132 & 0.034 & $\mathrm{D}$ \\
\hline \multirow[t]{4}{*}{$\begin{array}{l}\text { Proportion of } \\
\text { sire-herd variance }\end{array}$} & 0.00 & $0.004 \pm 0.004$ & 0.00 & - & - & A \\
\hline & $0.04 \pm 0.01$ & - & - & $0.02 \pm 0.01$ & 0.000 & B \\
\hline & - & $0.04 \pm 0.01$ & - & $0.01 \pm 0.01$ & 0.000 & $\mathrm{C}$ \\
\hline & - & - & $0.05 \pm 0.02$ & $0.02 \pm 0.01$ & 0.000 & $\mathrm{D}$ \\
\hline \multirow[t]{4}{*}{ Heritability } & $0.35 \pm 0.04$ & $0.39 \pm 0.04$ & $0.36 \pm 0.04$ & - & - & A \\
\hline & $0.30 \pm 0.05$ & - & - & $0.55 \pm 0.04$ & $0.56 \pm 0.04$ & B \\
\hline & - & $0.34 \pm 0.04$ & - & $0.55 \pm 0.04$ & $0.56 \pm 0.04$ & $\mathrm{C}$ \\
\hline & - & - & $0.30 \pm 0.04$ & $0.55 \pm 0.04$ & $0.56 \pm 0.04$ & $\mathrm{D}$ \\
\hline \multirow[t]{4}{*}{ Repeatability } & $0.55 \pm 0.01$ & $0.54 \pm 0.01$ & $0.55 \pm 0.01$ & - & - & A \\
\hline & $0.51 \pm 0.02$ & - & - & $0.71 \pm 0.01$ & $0.75 \pm 0.01$ & B \\
\hline & - & $0.50 \pm 0.02$ & - & $0.71 \pm 0.01$ & $0.75 \pm 0.01$ & $\mathrm{C}$ \\
\hline & - & - & $0.50 \pm 0.01$ & $0.71 \pm 0.01$ & $0.75 \pm 0.01$ & $\mathrm{D}$ \\
\hline
\end{tabular}

$†$ Model A included MY, FY and PY; model B included MY, FC and PC; model C included FY, FC and PC; and model D included $\mathrm{PY}, \mathrm{FC}$ and $\mathrm{PC}$.

(Grosshans et al., 1997) and US Holsteins (778 days, $\mathrm{SD}=89)($ Cole $\&$ Null, 2010). This high variability may be related to differences between nutritional and other environmental conditions in this population. The estimate of heritability for AF was small (0.01) (Table 2). Estimates for US Holsteins (0.03) (Cole \& Null, 2010) and for Canada (0.09) (Jamrozik et al. 2005) were also small, but not as small. Larger estimates above 0.20 were obtained in studies with different dairy breeds (e.g., Ruiz-Sánchez et al. 2007). It is worth mentioning, however, that many of the estimates for this trait have been obtained with models lacking a sire-herd effect. The sire-herd effect on $\mathrm{AF}$, measured as a proportion of phenotypic variance, was larger in this study (0.10) than the additive genetic effects. This magnitude of the sire-herd variance may imply that daughters of specific sires may receive shared management practices, creating a confounding between sire genetic and environmental effects (Pirlo et al.,
2000; Cienfuegos-Rivas et al., 2006), which may also explain why estimates of heritability for this trait span such a wide range across studies. The sire-herd proportion of phenotypic variance was generally small for other traits (Tables 2 and 3). Inclusion of sire-herd random effects in the model for analyzing AF was necessary to avoid obtaining inflated heritability estimates (Clément et al., 2001).

The average CI in this population (374 days) was similar to the average for dairy cattle in New Zealand for first (375 days) and second (365 days) CI (Grosshans et al., 1997) but was lower than the value of 404 days for US Holsteins recorded for the period 1980-2004 (Hare et al., 2006). The unadjusted phenotypic variability for CI was larger in this population ( $\mathrm{SD}=54$ days) at 24 to 26 days than for first and second CI, respectively, in New Zealand dairy cattle (Grosshans et al., 1997). The heritability estimate for CI was very 
low (0.002) (Table 2). In other studies, estimates for the heritability of CI or closely related traits such as days open, albeit low, has been in the range of 0.01-0.07 (Mark, 2004; Mostert et al., 2010). The sire-herd proportion of the phenotypic variance estimate was zero for this trait (Table 2). Heritability estimates in several reproductive traits including $\mathrm{CI}$ in grazing New Zealand cows in a seasonal production system (Grosshan al., 1997) were also low (0.01 to 0.06 ) but slightly higher than those found in this study.

The reason for the low heritability value for $\mathrm{CI}$ found here is not clear, but the average $\mathrm{CI}$ in this population is low, which suggests good reproductive management and therefore a favorable environment for fertility. However, the phenotypic variability found for CI is high. Most of this variability is within herd-years (Tables 1 and 2). Conversely, the mean value of AF for this population was larger than typical values for other dairy populations, making it difficult to relate these averages to heritability values for these traits.

Heritability estimates for MY, FY and PY were in the range of 0.29 to 0.36 and were very similar between single-trait (Table 2) and multi-trait models (Table 3). These values are moderately higher than the estimates by Uribe \& Smulders (2004) for the same population, ranging from 0.20 to 0.29 , and higher than estimates for the Holstein breed in Chile, ranging from 0.15 to 0.21 (Montaldo et al., 2015) or for the Holstein breed in Mexico, ranging from 0.12 to 0.23 (Montaldo et al., 2010). The estimates obtained in this study are similar to the values considered typical for many dairy breeds in a range of countries (Mark, 2004). It is not clear why heritability estimates are larger in this breed than in Holsteins. Possible explanations may include the greater initial genetic variation in this population or the acceptance of animals with up to $25 \%$ of red Holstein lineage in the breed. Other reasons, such as differences in the within-herd management effects, or genotypeby-environment interaction effects implying different environmental sensitivity across breeds, may also be involved. However, these increased heritability values were found only for milk yield traits, not for reproduction traits. Relatively high heritability values for yield traits allow reliable genomic predictions to be obtained even with moderately sized reference populations (Buch et al., 2012; Stock \& Reents, 2013).

The heritabilities for FC and PC were relatively high ( 0.55 to 0.56$)$ and were similar for singleand multi-trait analyses (Tables 2 and 3). These values are similar to estimates from other dairy cattle populations (Castillo-Juarez et al., 2002) and to typical values used in genetic evaluations in a range of dairy populations worldwide (Mark, 2004).

The repeatability values were in all cases greater than and proportional to the heritabilities. The repeatability estimates were 0.05 for CI (Table 2), from 0.50 to 0.55 for MY, FY and PY (Tables 2 and 3 ), and from 0.72 to 0.75 for FC and PC. From these values we may conclude that permanent effects, which may include both environmental and non-additive genetic effects, are more important than additive genetic effects for CI. The ratio of permanent effects variance to additive genetic variance decreased for production traits and to an even greater extent for content traits (Tables 2 and 3 ).

The genetic correlation estimates were high and positive $(\geq 0.70)$ between MY, FY and PY and moderately negative, from -0.32 to -0.34 (Table 4), between MY and FC and PC. These values are similar to those obtained from previous research results on dairy cattle populations in many countries (Mark, 2004).

AF was negatively correlated to MY (-0.71) and PY (-0.65). The genetic correlation between AF and FY was also negative (-0.29), but with a high standard error (Table 4). These correlations suggest that selection for an objective that includes MY, FY and PY would decrease AF and is therefore favorable; however, the effect on AF would be 
small due to the low heritability value. Seykora \& McDaniel (1983) also found favorable genetic correlations between yield and age at first calving, ranging from -0.10 to -0.36 , in a study with US Holsteins. Conversely, Grosshans et al. (1997) found unfavorable (positive) genetic correlations in the range 0.21 and 0.70 between AF and milk yield traits for New Zealand dairy cattle. They used a sire model that did not include a sire-herd term for the analysis.

The genetic correlations between CI and MY, FY and PY were considered non-estimable because they had large standard errors related to the fact that the genetic variance for $\mathrm{CI}$ is close to zero (Tables 2, 3 and 4). Unfavorable relationships between CI, days open, or other reproduction traits and milk yield traits have been found in studies involving different breeds of cattle (Pryce et al., 2000; Pryce et al, 2004). Albarran-Portillo
\& Pollott (2013) found unfavorable genetic correlations between CI and milk yield traits in the range of 0.50 to 0.73 , similar to previous estimates by Seykora \& McDaniel (1983) with a range of 0.35 to 0.60 ; Haile-Mariam et al. (2003) found also unfavorable relationships in the range of 0.43 to 0.58 , and Wall et al. (2003) found a value of 0.47 . Further studies with larger data sets are needed to clarify this issue in the study population; however, with such low heritability for CI, the importance of genetically correlated responses in CI to selection for milk yield traits is low.

The phenotypic correlation estimates between MY and FY and PY, between MY and FC and PC, between FY and PY and content traits, and between FC and PC (Table 4) were very similar to their corresponding genetic correlations, indicating that environmental covariances are of similar

Table 4. Estimates of genetic and phenotypic correlations for Dairy Overo Colorado cattle.

\begin{tabular}{|c|c|c|c|c|}
\hline Trait $\mathrm{x}$ & Trait y & Genetic correlation & Phenotypic correlation & Model $\dagger$ \\
\hline Milk yield & Fat yield & $0.70 \pm 0.04$ & $0.81 \pm 0.006$ & A \\
\hline Milk yield & Protein yield & $0.90 \pm 0.01$ & $0.94 \pm 0.002$ & A \\
\hline Milk yield & Fat content & $-0.32 \pm 0.08$ & $-0.23 \pm 0.017$ & B \\
\hline Milk yield & Protein content & $-0.34 \pm 0.09$ & $-0.30 \pm 0.016$ & B \\
\hline Fat yield & Protein yield & $0.83 \pm 0.02$ & $0.86 \pm 0.005$ & A \\
\hline Fat yield & Fat content & $0.51 \pm 0.06$ & $0.02 \pm 0.018$ & $\mathrm{C}$ \\
\hline Fat yield & Protein content & $0.20 \pm 0.08$ & $0.52 \pm 0.014$ & $\mathrm{C}$ \\
\hline Protein yield & Fat content & $0.00 \pm 0.08$ & $-0.08 \pm 0.016$ & $\mathrm{D}$ \\
\hline Protein yield & Protein content & $0.13 \pm 0.08$ & $0.26 \pm 0.015$ & $\mathrm{D}$ \\
\hline Fat content & Protein content & $0.67 \pm 0.04$ & $0.83 \pm 0.025$ & B \\
\hline Age at first calving & Calving interval & - & $-0.07 \pm 0.03$ & $\mathrm{E}+$ \\
\hline Age at first calving & Milk yield & $-0.71 \pm 0.24$ & $-0.05 \pm 0.03$ & $\mathrm{~F}$ \\
\hline Age at first calving & Fat yield & $-0.29 \pm 0.25$ & $-0.02 \pm 0.02$ & $\mathrm{~F}$ \\
\hline Age at first calving & Protein yield & $-0.65 \pm 0.24$ & $-0.02 \pm 0.03$ & $\mathrm{~F}$ \\
\hline Calving interval & Milk yield & - & $0.09 \pm 0.02$ & $\mathrm{G} \ddagger$ \\
\hline Calving interval & Fat yield & - & $0.06 \pm 0.03$ & $\mathrm{H} \stackrel{+}{\dagger}$ \\
\hline Calving interval & Protein yield & - & $0.07 \pm 0.04$ & $\mathrm{I}+$ \\
\hline
\end{tabular}

$\lceil$ Model A included MY, FY and PY; model B included MY, FC and PC; model C included FY, FC and PC; model D included PY, FC and PC; model E included AF and CI; model F included AF, MY, FY and PY; and models G, H and I included CI with MY, FY and PY, respectively.

$\ddagger$ Models E, G, H and I were used only to estimate phenotypic correlations. 
sign to their corresponding genetic covariances for these pairs of traits (with the exception of the phenotypic correlation between FY and FC, which was close to zero, implying a negative environmental covariance).

The phenotypic correlations between AF and CI and $\mathrm{MY}$ and between FY and PY were much closer to zero than the genetic correlations, revealing the presence of smaller environmental covariances than the genetic ones. These estimates do not provide evidence of an unfavorable phenotypic relationship between CI and milk yield in this population, which coincides with results from some previous studies (Grosshans et al., 1997; Albarran-Portillo \& Pollott, 2013).

The use of a repeatability model with 305-day records is not theoretically ideal for the estimation of genetic parameters or for genetic evaluation purposes because some assumptions, such as homogeneous correlations and variances between records of different lactations, are rarely fulfilled. This fact has stimulated the development of other options for genetic evaluation of dairy cows such as accounting for individual lactation records as correlated traits, as well as the use of methods that allow for a more flexible use of incomplete data by using random regression test-day methodology (Mark, 2004). Random regression test-day methods are, however, not free of numerical and methodological problems, which implies a need for more complex decision-making processes to define the correct model for obtaining unbiased estimates of the genetic parameters and estimated breeding values (Meyer, 2005). From the practical point of view, implementation of multi-trait selection methodology is more difficult when using test-day approaches because of the highly parameterized models (Mrode, 2005). Thus, more complex and time-consuming analyses are needed to estimate the required genetic parameters and predict the genetic values of the animals. Schaeffer et al. (2000) estimated the correlations between EBV obtained from 305-day lactation EBV and testday random regression EBV as 0.97 and 0.93 for bulls and cows, respectively, in Canadian Holstein cattle. Current genetic evaluation procedures used in US dairy cattle are based on single-trait 305day lactation repeatability models (VanRaden et al., 2007), while in Canada, a multi-trait test-day random regression model is used. Genetic correlations between Canadian and US populations for milk yield traits have been found to be close to 1 (Interbull, 2013). This indicates that the use of random regression models rather than the 305-day repeatability models currently used for genetic evaluation in Dairy Overo Colorado cattle is unlikely to yield dramatic changes in the ranking of selection candidates.

In conclusion, genetic variation is considerable for milk yield traits in the Dairy Overo Colorado breed, favoring the design of a breeding program within this population. Genetic advances from selection would be slow for age at first calving and particularly for calving interval. Genetic correlations showed that no antagonistic relationships exist between milk yield traits; however, genetic correlations between milk yield and fat content and between milk yield and protein content were unfavorable. Selection for increased milk yield, fat yield and protein yield may decrease age at first calving. There is no antagonism between milk production traits and reproductive efficiency at the phenotypic level.

\section{Acknowledgments}

The authors thank PAPIIT-UNAM, Mexico, for financial support and COOPRINSEM, Osorno, Chile, for providing data. H. H. Montaldo is a member of the National Research System of Mexico. 


\section{Resumen}

H.H. Montaldo, C. Trejo, y C. Lizana 2017. Parámetros genéticos para producción de leche y características de reproducción en la raza chilena Overo Colorado Lechero. Cien. Inv. Agr. 44(1): 24-34. El objetivo de este estudio fue estimar parámetros genéticos para características de producción de leche y reproducción en la raza Overo Colorado Lechero del sur de Chile. Se utilizaron modelos de una y múltiples características para analizar los datos. Los análisis se realizaron usando el programa ASReml. Los estimados de heredabilidad para producción de leche, producción de grasa, producción de proteína, contenido de grasa, contenido de proteína, edad al primer parto e intervalo entre partos fueron $0.29 \pm 0.04,0.34$ $\pm 0.04,0.30 \pm 0.04,0.56 \pm 0.04,0.56 \pm 0.04,0.01 \pm 0.07$ y $0.002 \pm 0.02$, respectivamente Las correlaciones genéticas entre las características de producción fueron altas y positivas $(\geq$ 0.81). Las correlaciones genéticas de la producción de leche con el contenido de grasa (-0.32) y el contenido de proteína (-0.34) fueron desfavorables. La correlación genética entre edad al primer parto y las características de producción fueron negativas entre -0.71 and -0.29 . Las correlaciones fenotípicas entre el intervalo entre partos y las características de producción de leche fueron ligeramente positivas, (0.06-0.09), lo que sugiere una relación débil entre reproducción y producción en esta población. La variación genética es significativamente mayor a cero para las características de producción de leche. El mejoramiento genético para edad al primer parto e intervalo entre partos será lento, debido a que se esperan pequeñas diferencias entre animales y bajas confiabilidades para los valores genéticos estimados, debido a que los valores de las heredabilidades son cercanos a cero. El diseño de un programa eficiente de mejoramiento genético para características de producción basado en inseminación artificial para esta población es factible usando pruebas de progenie o predicciones del valor genético aditivo usando evaluaciones genómicas para la selección de sementales.

Palabras clave: Raza bovina local, Chile, mejoramiento genético, heredabilidad, correlación.

\section{References}

Åkesson M, S. Bensch, D. Hasselquist, M. Tarka, and B. Hansson. 2008. Estimating heritabilities and genetic correlations: Comparing the «animal model» with parent-offspring regression using data from a natural population. PLoS ONE 3:e1739.

Albarran-Portillo B., and G.E. Pollott. 2013. The relationship between fertility and lactation characteristics in Holstein cows on United Kingdom commercial dairy farms. J. Dairy Sci. 96:635646.

Buch L.H., M.K. Sørensen, P. Berg, L.D. Pedersen, and A.C. Sørensen. 2012. Genomic selection strategies in dairy cattle: Strong positive interac- tion between use of genotypic information and intensive use of young bulls on genetic gain. J. Anim. Breed. Genet. 129:138-151.

Castillo-Juarez, H., P.A. Oltenacu, and E.G. Cienfuegos-Rivas. 2002. Genetic and phenotypic relationships among milk production and composition traits in primiparous Holstein cows in two different herd environments. Livest. Prod. Sci. 78:223-231.

Cienfuegos-Rivas E.G., R.W. Blake, P.A. Oltenacu, and H. Castillo-Juarez. 2006. Fertility responses of Mexican Holstein cows to US sire selection. J. Dairy Sci. 89:2755-2760.

Clément, V., B. Bibé, É. Verrier, J.M. Elsen, E. Manfredi, J. Bouix, and É. Hanocq. 2001. Simulation analysis to test the influence of model adequacy 
and data structure on the estimation of genetic parameters for traits with direct and maternal effects. Genet. Sel. Evol. 33:369-395.

Cole J.B., and D.J. Null. 2010. Age at First Calving in Holstein Cattle in the United States. J. Dairy Sci. 93(E-Suppl 1):594.

FAO. 2007. The State of the World's Animal Genetic Resources for Food and Agriculture. Rome.

Ferreira, O., F. Mujica, H. Uribe, F. Lanuza, G. Quinteros, and C. Concha. 2010. El control lechero bovino en Chile y su importancia en el mejoramiento genético del rebaño nacional. Agro Sur 38:178-193.

Gilmour, A.R., B.J. Gogel, B.R. Cullis, and R. Thompson. 2009. ASReml user guide. Release 3.0.VSN International Ltd, U.K.

Grosshans, T., Z.Z. Xu, L.J. Burton, D.L. Johnson, and K.L. Macmillan. 1997. Performance and genetic parameters for fertility of seasonal dairy cows in New Zealand. Livest. Prod. Sci. 51:41-51.

Haile-Mariam, M., P.J. Bowman, and M.E. Goddard. 2003. Genetic and environmental relationship among calving interval, survival, persistency of milk yield and somatic cell count in dairy cattle. Livest. Prod. Sci. 80:189-200.

Hare, E., H. D. Norman, and J. R. Wright. 2006. Trends in Calving Ages and Calving Intervals for Dairy Cattle Breeds in the United States. J. Dairy Sci. 89:365-370.

Interbull. 2013. Interbull Routine Genetic Evaluation for Dairy Production Traits. International Bull Evaluation Service, Uppsala, Sweden.

Jamrozik, J., J. Fatehi, G.J., Kistemaker, and L.R. Schaeffer. 2005. Estimates of genetic parameters for Canadian Holstein female reproduction traits. J Dairy Sci. 88:2199-208.

Mark, T. 2004. Applied genetic evaluations for production and functional traits in dairy cattle. J. Dairy Sci. 87:2641-2652.

Meyer, K. 2005. Advances in methodology for random regression analysis. Austr. J. Exp. Agric. 45:847-858.

Montaldo H.H., H. Castillo-Juárez, C. Lizana, C. Trejo, E.G. Cienfuegos-Rivas, and A. PelcastreCruz. 2015. Genotype-environment interaction between Chile and North America and between Chilean herd environmental categories for milk yield traits in black and white cattle. Ani. Sci. Pap. Rep. 33:23-33.

Montaldo, H.H., H. Castillo-Juárez, M. ValenciaPosadas, E.G. Cienfuegos-Rivas, and F.J. RuizLópez. 2010. Genetic and environmental parameters for milk production, udder health, and fertility traits in Mexican Holstein cows. J. Dairy Sci. 93:2168-2175.

Mostert, B.E., R.R. Van der Westhuizen, and H.E. Theron. 2010. Calving interval genetic parameters and trends for dairy breeds in South Africa. S. Afr. J. Anim. Sci. 40:156-162.

Mrode, R.A. 2005. Linear models for the prediction of animal breeding values. 2nd ed. CABI Publishing $\mathrm{CAB}$ International. Wallingford, Oxfordshire, UK.

ODEPA. 2010. Dairy Bulletin-Year 2010. Ministry of Agriculture, Chile. http://www.odepa.gob. cl/odepaweb/servicios-informacion/Lacteos/ Leche-2010.pdf (accessed 29 Mar. 2011).

Oltenacu, P.A., and D.M. Broom. 2010. The impact of genetic selection for increased milk yield on the welfare of dairy cows. Anim. Welfare 19:39-49.

Pirlo, G., F. Miglior, and M. Speroni. 2000. Effect of age at first calving on production traits and on difference between milk yield returns and rearing costs in Italian Holsteins. J. Dairy Sci. 83:603-608.

Pryce, J.E., M.P. Coffey, and S. Brotherstone. 2000. The genetic relationship between calving interval, body condition score and linear type and management traits in registered Holsteins $\mathrm{J}$. Dairy Sci. 83:2664-2671.

Pryce, J.E., M.D. Royal, P.C. Garnsworthy, and I.L. Mao. 2004. Fertility in the high-producing dairy cow. Livest. Prod. Sci. 86:125-135.

Ruiz-Sánchez, R., R.W. Blake, H.M.A. CastroGámez, F. Sánchez, H.H. Montaldo, and H. Castillo-Juárez. 2007. Changes in the association between milk yield and age at first calving in Holstein cows with herd environment level for milk yield. J. Dairy Sci. 90:4830-4834.

Seykora A.J., and B.T. McDaniel. 1983. Heritabilities and correlations of lactation yields and 
fertility for Holsteins. J. Dairy Sci. 66:14861493.

Schaeffer, L.R., J. Jamrozik, G.J. Kistemaker, and J. Van Doormaal. 2000. Experience with a test-day model. J. Dairy Sci. 83:1135-1144.

Stock, K.F., and R. Reents. 2013. Genomic Selection: Status in Different Species and Challenges for Breeding. Reprod. Domest. Anim. 48 (Suppl. 1):2-10.

Uribe, H.A., and J.P. Smulders. 2004. Estimation of parameters and phenotypic, genetic and environmental trends for milk yield traits in Overo Colorado cattle. Arch. Med. Vet. 36:137-146.
VanRaden, P.M., A.H. Sanders, M.E. Tooker, R.H. Miller, H.D. Norman, M.T. Kuhn, and G.R. Wiggans. 2004. Development of a national genetic evaluation for cow fertility. J. Dairy Sci. 87:2285-2292.

VanRaden, P.M., M.E. Tooker, J.B. Cole, G.R. Wiggans, and J.H. Megonigal. 2007. Genetic evaluations for mixed-breed populations. J. Dairy Sci. 90:2434-2441.

Wall, E., S. Brotherstone, J.A. Woolliams, G. Banos, and M.P. Coffey. 2003. Genetic evaluation of fertility using direct and correlated traits. J Dairy Sci. 86:4093-4102. 